\title{
ANALISIS MANAJEMEN RISIKO PADA KANTOR PUSAT PT. BANK BENGKULU
}

\author{
Dian Wundari Gustini \\ Sulisti Afriani \\ Program Studi Akuntansi \\ Fakultas Ekonomi Universitas Dehasen Bengkulu
}

\begin{abstract}
ABSTRAK
Dian Wundari Gustini, Sulisti Afriani; Analisis Manajemen Risiko Pada Kantor Pusat PT. Bank Bengkulu. Penelitian ini bertujuan untuk mengetahui Analisis Manajemen Risiko Pada Kantor Pusat PT. Bank Bengkulu. Jenis penelitian adalah penelitian deskriktif. Dalam penelitian ini sampel yang digunakan berupa laporan kualitas penerapan manajemen risiko PT. Bank Bengkulu Tahun 2012. Dengan laporan risiko ini dapat menggambarkan kondisi PT. Bank Bengkulu serta dapat dianalisis tingkat kualitas penerapannya. Untuk analisa kuantitatif menggunakan penilaian risiko inheren, yang merupakan penilaian atas risiko melekat kegiatan bisnis Bank, baik yang dapat dikuantifikasikan ataupun yang tidak, dan berpotensi mempengaruhi posisi keuangan Bank. Adapun analisa kualitatif menggunakan indikator Kualitas Penerapan Manajemen Risiko dengan kriteria dan parameter yang telah ditentukan oleh Bank Indonesia. Dari penelitian ini menunjukkan gambaran Penerapan manajemen risiko di PT. Bank Bengkulu secara rata-rata nilainya 2,50 berada pada interval 1,81-2,60 dengan kriteria Satisfactory yaitu Kualitas penerapan manajemen risiko PT. Bank Bengkulu secara komposit memadai, meskipun terdapat kelemahan minor, tetapi kelemahan tersebut perlu mendapatkan perhatian manajemen PT. Bank Bengkulu untuk melakukan perbaikan. Penilaian terhadap kualitas implementasi manajemen risiko pada PT Bank Bengkulu dapat ditelusuri dari tahapan-tahapan penyusunan strategi, program, kebijakan, sasaran, dan implementasinya.
\end{abstract}

\begin{abstract}
Dian Wundari Gustini, Sulisti Afriani; Analysis Of Risk Management in PT.Bank Bengkulu Office. This study aims to determine the Analysis Risk Management in PT. Bank Bengkulu Office. The type of is the study descriptive. In this study the samples used is the form of quality report application of risk management PT. Bank of Bengkulu in 2012. By the risk report can described the condition of PT. Bank Bengkulu and can be analyzed levels of application quality. For quantitative analysis using the inherent risk assessment, which is an assessment of the risks inherent Bank's business activities, both of which can be quantified or are not, and could potentially affect the financial position of the Bank. The qualitative analysis using indicators Quality Risk Management with the criteria and parameters that have been set by Bank Indonesia. This study showed an overview of the implementation of risk management at PT. Bank Bengkulu average value of 2.50 is in the interval from 1.81 to 2.60 with Satisfactory criteria is quality risk management of PT. Bank of Bengkulu in composite adequate, although there are minor flaws, but these flaws need to get the attention of the management of PT. Bank Bengkulu to make improvements. Assessment of the quality of risk management implementation in PT Bank Bengkulu can be traced from the stages of preparation of strategies, programs, policies, objectives, and implementation.
\end{abstract}

Kata kunci: Risk Management 


\section{PENDAHULUAN}

Bank merupakan perusahaan yang bergerak di bidang keuangan, artinya aktivitas perbankan selalu berkaitan dengan bidang keuangan. seperti telah ditegaskan dalam UndangUndang Nomor 10 tahun 1998 tanggal 10 November 1998 perubahan dari Undang-Undang Nomor 7 tahun 1992 tentang pebankan, yang menyatakan bahwa bank adalah badan usaha yang menghimpun dana dari masyarakat dalam bentuk simpanan dan menyalurkannya kepada masyarakat dalam bentuk kredit dan atau bentuk-bentuk lainnya dalam rangka meningkatkan taraf hidup orang banyak (Kasmir, 2013: 24).

Dana yang telah berhasil dihimpun oleh bank dialokasikan berbagai bentuk pengalokasian dana, salah satunya adalah pemberian kredit. Menurut Undang-Undang No.10 Tahun 1998 tentang perbankan, yang dimaksud dengan kredit adalah penyediaan uang atau tagihan yang dapat dipersamakan dengan itu, berdasarkan kesepakatan pinjam-meminjam antara pihak bank dengan pihak lain yang mewajibkan pihak peminjam untuk melunasi hutangnya setelah jangka waktu tertentu dengan pemberian bunga (Kasmir, 2013: 85). Bank Bengkulu merupakan bank yang tinggi tingkat penyaluran kreditnya sehingga Bank Bengkulu memiliki peranan yang sangat penting dalam menunjang dan mengembangkan pertumbuhan ekonomi di Provinsi Bengkulu.

Semakin banyak dana yang disalurkan tentu saja semakin besar potensi kemungkinan menimbulkan gagal bayar yang akan menimbulkan kredit bermasalah (non performing loan). Hal ini mengakibatkan risiko yang diitanggung Bank dari penerbitan produk dan pelaksanaan aktivitas menjadi semakin tinggi. Peningkatan risiko yang ditanggung oleh Bank harus diimbangi dengan pengendalian risiko yang memadai. Untuk mengendalikan risiko dimaksud Bank perlu meningkatkan kualitas penerapan manajemen risiko. Upaya peningkatan kualitas penerapan manajemen risiko yang dimaksud tidak hanya ditujukan bagi kepentingan Bank tetapi juga bagi kepentingan nasabah. Salah satu aspek penting dalam melindungi kepentingan nasabah dan dalam rangka pengendalian risiko adalah transparasi informasi terkait produk atau aktivitas Bank. Melalui peningkatan kualitas penerapan manajemen risiko, bank diharapkan dapat mengukur dan mengendalikan risiko yang dihadapi dalam melakukan kegiatan usahanya dengan lebih baik. Selanjutnya peningkatan kualitas penerapan manajemen risiko yang dilakukan perbankan akan mendukung efektivitas kerangka pengawasan bank berbasis risiko yang dilakukan oleh Bank Indonesia (PBI No. 11/25/PBI/2009). Situasi lingkungan eksternal dan internal perbankan yang mengalami perkembangan pesat diikuti dengan semakin kompleksnya risiko kegiatan usaha perbankan meningkatkan kebutuhan praktek tata kelola bank yang sehat (good).

Beberapa klasifikasi risiko yang digunakan oleh sebuah bank sesuai klasifikasi yang ditetapkan oleh Bank Indonesia, antara lain :
a. Risiko kredit
b. Risiko pasar
c. Risiko likuiditas
d. Risiko operasional
e. Risiko hukum
f. Risiko Stratejik
g. Risiko Kepatuhan
h. Risiko Reputasi

Proses penerapan manajemen risiko meliputi aktivitas identifikasi, pengukuran, pemantauan, dan pengendalian risiko. Identifikasi risiko yang dilakukan bersifat proaktif, mencakup seluruh aktivitas bisnis Bank dan dilakukan dalam rangka menganalisis sumber dan kemungkinan timbulnya risiko serta dampaknya. Selanjutnya, Bank perlu melakukan pengukuran risiko sesuai dengan karakteristik dan kompleksitas kegiatan usaha. Dalam pemantauan terhadap hasil pengukuran risiko, Bank menetapkan Satuan Kerja Manajemen Risiko untuk memantau tingkat dan tren serta menganalisis arah risiko. Selain itu, efektivitas penerapan manajemen risiko didukung oleh pengendalian risiko dengan mempertimbangkan hasil pengukuran dan pemantauan risiko. Dalam rangka mendukung proses identifikasi, 
pengukuran, pemantauan, dan pengendalian risiko, Bank juga mengembangkan sistem informasi manajemen yang disesuaikan dengan karakteristik, kegiatan dan kompleksitas kegiatan usaha Bank.

\section{TINJAUAN LITERATUR Risiko}

Risiko dan bank adalah dua hal yang tidak dapat dipisahkan satu sama lainnya, tanpa adanya keberanian untuk mengambil risiko maka tidak akan pernah ada bank, dalam artian bahwa bank muncul karena keberanian untuk berisiko dan bahkan bank mampu bertahan karena berani mengambil risiko. Namun jika risiko tersebut tidak dikelola dengan baik, bank dapat mengalami kegagalan bahkan pada akhirnya mengalami kebangkrutan.

Dalam kamus besar bahasa Indonesia Risiko adalah kemungkinan, bahaya, kerugian, akibat kurang menyenangkan dari sesuatu perbuatan, usaha, dan sebagainya. Menurut Soehatman Ramli (2010:27), risiko merupakan kombinasi dari kemungkinan dan keparahan dari suatu kejadian. Besarnya risiko ditentukan oleh berbagai faktor, seperti besarnya paparan, lokasi, pengguna, kuantiti serta kerentanan unsur yang terlibat.

Risiko menurut pandia (2012: 199) adalah ancaman atau kemungkinan suatu tindakan atau kejadian yang menimbulkan dampak yang berlawanan dengan tujuan yang ingin dicapai. Dengan kata lain risiko merupakan kemungkinan menderita kerugian karena kehilangannya sebagian atau seluruh modal. Risiko sendiri ditimbulkan karena adanya ketidakpastian.

Dari pengertian-pengertian risiko di atas dapat kita simpulkan bahwa risiko selalu dihubungkan dengan kemungkinan terjadinya sesuatu yang merugikan yang tidak diduga/tidak diharapkan. Dengan demikian risiko ini mempunyai karakteristik :

a. Merupakan ketidak pastian atas terjadinya suatu peristiwa

b. Merupakan ketidak pastian yang bila terjadi akan menimbulkan kerugian.

Jadi ketidakpastian merupakan kondisi yang menyebabkan timbulnya risiko. Kondisi ketidakpastian sendiri timbul karena berbagai sebab, antara lain :

a. Tenggang waktu antara perencanaan suatu kegiatan sampai kegiatan itu berakhir, dimana makin panjang tenggang waktunya akan makin besar ketidakpastiannya.

b. Keterbatasan informasi yang tersedia yang diperlukan untuk penyusunan rencana.

c. Keterbatasan pengetahuan/kemampuan pengambilan keputusan dari perencana.

\section{Manajemen Risiko}

Dalam kaitannya dengan pengelolaan risiko, Bank dituntut melakukan manajemen risiko yang sehat. Menurut Pandia (2012:198), pengertian manajemen risiko secara sederhana adalah pelaksanaan fungsi-fungsi manajemen dalam penanggulangan risiko, terutama risiko yang dihadapi oleh organisasi atau perusahaan, keluarga dan masyarakat. Jadi mencakup kegiatan merencanakan, mengorganisir, menyusun, memimpin/ mengkoordinasi, dan mengawasi (termasuk mengevaluasi) program penanggulangan risiko.

Bank Indonesia melalui peraturan Bank Indonesia No.5/8/PBI/2003. Tanggal 19 Mei 2003 yang diuraikan lebih rinci dalam lampiran surat ederan Bank Indonesia No.5/21/DPNP Tanggal 29 September 2003 menjelaskan tentang pengertian manajemen risiko adalah, serangkaian prosedur dan metodologi yang digunakan untuk mengidentifikasikan, mengukur, memantau, dan mengendalikan risiko yang timbul dari kegiatan usaha bank.

Proses Manajemen risiko merupakan tindakan dari seluuh entitas terkait dalam organissasi. Tindakan berkesinambungan yang dialkukan sejalan dengan definisi manajemen risiko yang telah dikemukakan yaitu: identifikasi, kuantifikasi, menentukan sikap, menetapkan solusi, serta melakukan monitor dan pelaporan risiko, dapat dilihat pada gambar 1 . sebagai berikut menurut Pandia (2012; 201): 
Gambar 1. Proses Manajemen Risiko

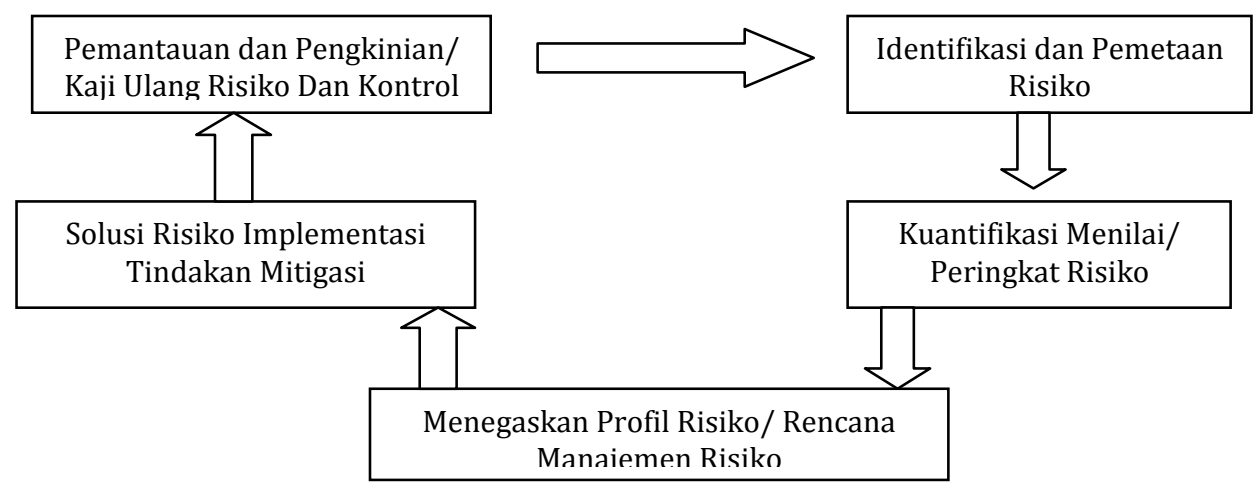

1. Melakukan Identifikasi dan Pemetaan Risiko

Identifikasi risiko bertujuan menemukan secara sistematis risiko (kerugian potensial) yang mungkin dihadapi usaha. Dalam hal ini apabila risiko tidak teridentifikasi, maka berarti usaha tersebut menanggung risiko secara tidak sadar.

2. Melakukan Kuantifikasi Menilai/ Peringkat Risiko

Melakukan aplikasi teknik permodelan dalam megukur risiko dan perluasan dengan memanfaatkan tolok ukur (bench marking), Permodelan (modeling), dan peramalan (forecasting) yang berasal dari luar organisasi. Sumber eksternal yang dimaksud berasal dari praktik-praktik terbaik yang telah dilakukan di dalam industri.

3. Menegaskan Profil Risiko/ Rencana Manajemen Risiko

Melakukan identifikasi selera risiko organisasi (risk appetite), apakah manajemen secara umum terdiri penghindaran risiko (risk aveter), penerima risiko sewajarnya (risk neutral), dan pencari risiko (risk seeker).

4. Solusi Risiko Implementasi Tindakan Mitigasi

a. Hindari (Avoidance)

Keputusan yang diambil adalah tidak melakukan aktivitas yang dimaksud. Artinya bank tidak harus mengambil keputusan untuk tidak melakukan aktivitas/ tindakan yang merugikan bank itu sendiri.

b. Alihkan (Transfer)

Artinya membagi risiko dengan pihak lain. Konsekuensinya terdapat biaya yang harus dikeluarkan atau berbagi keuntungan yang diperoleh.

c. Mitigasi Risiko (Mitigate Risk)

Artinya menerima risiko pada tingkat tertentu dengan melakukan tindakan untuk mitigasi risiko melalui peningkatan control, kualitas proses, serta aturan yang jelas terhadap pelaksanaan aktivitas dan risikonya.

d. Menahan Risiko Residual (Retention of Risidual Risk)

Artinya meneima risiko yang mingkin timbul dari aktivitas yang dilakukan. Ketersediaan menerima risiko ini dikaitkan dengan ketersediaan penyangga jika kerugian atas risiko terjadi.

5. Pemantauan dan Pengkinian/ Kaji Ulang Risiko Dan Kontrol

Dalam penyusunan permohonan kredit, bahasan mengenai aspek risiko bertujuan untuk menjelaskan mengenai layak tidaknya usaha tersebut dibiayai apabila terjadi perubahan-perubahan pada unsur-unsur kelayakan pemasaran, teknologi dan produksi serta keuangan. Kajian terhadap aspek risiko ini terutama untuk menyajikan dan menganalisis : pertama, faktor-faktor yang mempengaruhi besar kecilnya risiko kegagalan usaha yang mungkin akan dihadapi pengusaha. Kedua, aspek risiko dalam suatu analisis kelayakan usaha apabila dikemudian hari ternyata usaha ini akan diusulkan dan dibiayai oleh Bank. Ketiga, perumusan langkah-langkah yang perlu diantisipasi untuk bisa keluar dari risiko kegagalan usaha. 
Dalam konteks organisasi manejemen risiko, Bank tentu harus dapat menciptakan fungsi manajemen risiko yang independen terhadap Risk Taking Unit. Jadi, harus ada mengawasi dan diawasi. Bank harus mengembangkan kebijakan, metodologi dan infrastruktur yang dapat melindungi Bank dari kerugian akibat risiko disetiap sisi aktivitasnya.

Dalam kebijakan-kebijakan Bank harus menentukan tingkat toleransinya terhadap risiko yang tetap konsisten terhadap strategi usahanya, dan strategi itu sendiri harus menyatakan tujuan yang ingin dicapai dalam ukuran risiko dan target imbal hasil.

\section{Fungsi Pokok Manajemen Risiko}

Fungsi Manajemen Risiko pada pokoknya mencakup :

a. Menemukan kerugian potensial Artinya berupaya untuk menemukan/mengidentifikasi seluruh risiko murni yang dihadapi oleh perusahaan, yang meliputi :

1. Kerusakan phisik dari harta kekayaan perusahaan

2. Kehilangan pendapatan atau kerugian lainnya akibat terganggunya operasi perusahaan.

3. Kerugian akibat adanya tuntutan hukum dari pihak lain

4. Kerugian-kerugian yang timbul karena : penipuan, tindakan-tindakan kriminal lainnya, tidak jujurnya karyawan dan sebagainya.

5. Kerugian-kerugian yang timbul akibat "keyman" meninggal dunia, sakit atau menjadi cacat.

Untuk itu cara-cara yang dapat ditempuh oleh Manajer Risiko antara lain dengan : melakukan inspeksi phisik di tempat kerja, mengadakan angket kepada semua pihak di perusahaan, menganalisa semua variabel yang tercakup dalam peta aliran proses produksi dan sebagainya. Misalnya : dengan menganalisa bahan baku dan pembantu dapat diidentifikasi : kemungkinan kerugian karena jumlah pasokan yang tidak memadai, penyerahan yang tidak tepat waktu, kerusakan dan kehilangan pada saat penyimpanan; pada proses produksi dapat diidentifikasi : kemungkinan kerugian karena salah proses, kerusakan alat produksi, keterlambatan dan sebagainya; pada produk akhir : kemungkinan kerugian karena barang rusak/hilang dalam penyimpanan, penipuan/kecurangan dari penyalur dan sebagainya.

b. Mengevaluasi Kerugian Potensial

Artinya melakukan evaluasi dan penilaian terhadap semua kerugian potensial yang dihadapi oleh perusahaan. Evaluasi dan penilaian ini akan meliputi perkiraan mengenai :

1. Besarnya kemungkinan frekuensi terjadinya kerugian, artinya memperkirakan jumlah kemungkinan terjadinya kerugian selama suatu periode tertentu atau berapa kali terjadinya kerugian tersebut selama suatu periode tertentu (biasanya 1 tahun).

2. Besarnya kegawatan dari tiap-tiap kerugian, artinya menilai besarnya kerugian yang diderita, yang biasanya dikaitkan dengan besarnya pengaruh kerugian tersebut, terutama terhadap kondisi finansial perusahaan.

3. Memilih teknik/cara yang tepat atau menentukan suatu kombinasi dari teknik-teknik yang tepat guna menanggulangi kerugian.

\section{Klasifikasi Risiko}

Risiko dapat diartikan dalam berbagai cara, namun pengertian risiko yang paling umum adalah seluruh hal yang dapat mengakibatkan penyimpangan dari tujuan yang ingin dicapai Bank. Bank Indonesia melalui Peraturan Bank Indonesia No. 11/25/PBI/2009 tentang Penerapan Manajemen Risiko bagi Bank Umum per 1 Juli 2010 membagi risiko keuangan dalam kelompok sebagai sebagai berikut:

1. Risiko kredit adalah risiko akibat kegagalan debitur dan atau pihak lain dalam memenuhi kewajiban kepada Bank. Termasuk dalam risiko kredit adalah risiko konsentrasi kredit. Risiko konsentrasi kredit merupakan risiko yang timbul akibat terkonsentrasinya penyediaan dana kepada 1 (satu) pihak atau sekelompok pihak, industri, sektor, dan atau 
area geografis tertentu yang berpotensi menimbulkan kerugian cukup besar yang dapat mengancam kelangsungan usaha Bank.

2. Risiko pasar adalah risiko pada posisi neraca dan rekening administratif termasuk transaksi derivatif, akibat perubahan secara keseluruhan dari kondisi pasar, termasuk risiko perubahan harga option. Jenis dari risiko pasar meliputi:

a. Risiko Suku Bunga adalah risiko kerugian akibat perubahan harga instrumen keuangan dari posisi Trading Book yang disebabkan oleh perubahan suku bunga.

b. Risiko Nilai Tukar adalah risiko kerugian akibat perubahan nilai posisi Trading Book dan Banking Book yang disebabkan oleh perubahan nilai tukar valuta asing termasuk perubahan harga emas.

c. Risiko Ekuitas adalah risiko kerugian akibat perubahan harga instrumen keuangan dari posisi Trading Book yang disebabkan oleh perubahan harga saham.

d. Risiko Komoditas adalah risiko kerugian akibat perubahan harga instrumen keuangan dari posisi Trading Book dan Banking Book yang disebabkan oleh perubahan harga komoditas.

e. Risiko Spesifik adalah risiko perubahan harga instrumen keuangan akibat faktor-faktor yang berkaitan dengan penerbit instrumen keuangan.

f. Risiko Umum adalah risiko perubahan harga instrumen keuangan akibat perubahan faktor-faktor pasar.

g. Trading Book adalah seluruh posisi instrumen keuangan dalam neraca dan rekening administratif termasuk transaksi derivatif yang dimiliki untuk:

1) Tujuan diperdagangkan dan dapat dipindahtangankan dengan bebas atau dapat dilindung nilai secara keseluruhan, baik dari transaksi untuk kepentingan sendiri (proprietary positions), atas permintaan nasabah maupun kegiatan perantaraan (brokering), dan dalam rangka pembentukan pasar (market making)

2) Tujuan lindung nilai atas posisi lainnya dalam Trading Book.

h. Banking Book adalah semua posisi lainnya yang tidak termasuk dalam Trading Book.

3. Risiko likuiditas adalah risiko akibat ketidakmampuan Bank untuk memenuhi kewajiban yang jatuh tempo dari sumber pendanaan arus kas dan atau dari aset likuid berkualitas tinggi yang dapat diagunkan, tanpa mengganggu aktivitas dan kondisi keuangan Bank.

4. Risiko operasional adalah risiko akibat ketidakcukupan dan atau tidak berfungsinya proses internal, kesalahan manusia, kegagalan sistem, dan atau adanya kejadian-kejadian eksternal yang mempengaruhi operasional Bank.

5. Risiko hukum adalah risiko akibat tuntutan hukum dan atau kelemahan aspek yuridis.

6. Risiko stratejik adalah risiko akibat ketidaktepatan dalam pengambilan dan/atau pelaksanaan suatu keputusan stratejik serta kegagalan dalam mengantisipasi perubahan lingkungan bisnis.

7. Risiko reputasi adalah risiko akibat menurunnya tingkat kepercayaan stakeholder yang bersumber dari persepsi negatif terhadap Bank.

8. Risiko kepatuhan adalah risiko akibat Bank tidak mematuhi dan atau tidak melaksanakan peraturan perundang-undangan dan ketentuan yang berlaku.

\section{Penetapan Bobot Penilaian Risiko}

Penetapan bobot dalam penilaian parameter risiko inheren dan kualitas penerapan manajemen risiko ditentukan secara weighted average antara banyaknya jumlah pertanyaan dalam penilaian risiko inheren dan kualitas penerapan manajemen risikonya baik untuk kelompok jenis risiko dan risiko komposit. Ketentuan bobot untuk setiap jenis risiko dalam Surat Keputusan Direksi Bank Bengkulu No.100/HP.00.02.03/D.9/2011 Tgl. 25 Nopember 2011 adalah sebagai berikut:

1. Untuk penilaian parameter risiko inheren digunakan bobot sebagai berikut:

a. Nilai 1 jika parameter yang dinilai memiliki karakteristik risiko low

b. Nilai 2 jika parameter yang dinilai memiliki karakteristik risiko low to moderat

c. Nilai 3 jika parameter yang dinilai memiliki karakteristik risiko moderat 
d. Nilai 4 jika parameter yang dinilai memiliki karakteristik risiko moderat to high

e. Nilai 5 jika parameter yang dinilai memiliki karakteristik risiko high

2. Untuk penilaian parameter kualitas penerapan manajemen risiko digunakan bobot sebagai berikut :

a. Nilai 1 jika parameter yang dinilai memiliki karakteristik kualitas strong

b. Nilai 2 jika parameter yang dinilai memiliki karakteristik kualitas satisfactory

c. Nilai 3 jika parameter yang dinilai memiliki karakteristik kualitas fair

d. Nilai 4 jika parameter yang dinilai memiliki karakteristik kualitas marginal

e. Nilai 5 jika parameter yang dinilai memiliki karakteristik kualitas unsatisfactory

Sedangkan setiap pertanyaan yang dinilai oleh User memiliki bobot tertimbang sebesar $\frac{1}{N}$, sehingga jumlah semua nilai sama dengan 1 . Hasil perkalian antara bobot $\frac{1}{N}$ dengan nilai parameter akan menghasilkan nilai score yang kemudian dipetakan berdasarkan skala penilaian sebagai berikut :

\section{Gambar 2. Cara Menghitung Penilaian Risiko Inherent dan Kualitas Penerapan Manajemen Risiko}

\begin{tabular}{|c|c|c|}
\hline Risiko inheren & Fange & Skor \\
\hline Low & $I$ & $\leq 1.8$ \\
\hline Low to Moderate & $>1.8$ & $\leq 2.6$ \\
\hline Moderate & $>2.6$ & $\leq 3.4$ \\
\hline Moderato to High & $>3.4$ & $\leq 4.2$ \\
\hline HIEh & $>4.2$ & $\leq 5$ \\
\hline Kualitas penerapan Manajemen Risiko & Range & skor \\
\hline Strong & 1 & $\leq 1.8$ \\
\hline Satisfactory & $>1.8$ & $\leq 2.6$ \\
\hline Fair & $>2.6$ & $\leq 3.4$ \\
\hline Marginal & $>3.4$ & $\leq 4.2$ \\
\hline Unsatisfactory & $>4.2$ & $\leq 5$ \\
\hline
\end{tabular}

Sumber: PT. Bank Bengkulu, 2012

\section{Kerangka Analisis}

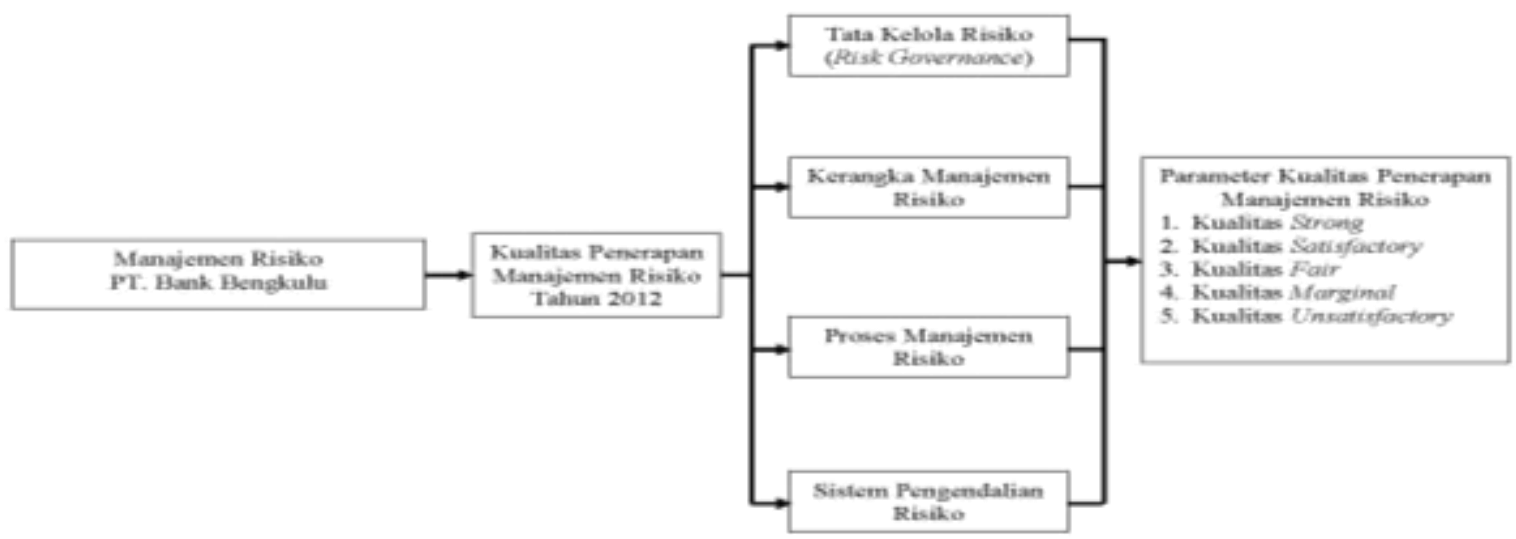

Gambar 2. Kerangka Analisis

\section{HASIL PENELITIAN DAN PEMBAHASAN Penilaian Kualitas Penerapan Manajemen Risiko}

Analisis dilakukan sesuai dengan isian form baku yang sudah disediakan oleh Bank Indonesia dan dijadikan standar penilaian yang disesuailam dengan kondisi dan bisnis di PT. Bank Bengkulu. Pengisian form dilakukan melalui kuesioner yang wajib di isi setiap bulannya oleh 9 (Sembilan) Divisi dan 1 (satu) bagian yang berkaitan dengan masing-masing risiko yang 
dikelolanya, hasil kuesionar tersebut dimasukkan secara tersistem melalui Risk Profile System yang dimiliki oleh Bank, sehingga dari hasil pengisian form/ data akan menghasilkan output berupa Laporan Profile Risiko Bank yang kemudian dilaporkan kepada Bank Indonesia setiap triwulannya.

a. Tata Kelola Risiko (Risk Governance)

Isian pertama adalah form laporan hasil penilaian tata kelola risiko (Risk Governance) PT. Bank Bengkulu yang memaparkan tata kelola risiko mencakup evaluasi terhadap: 1) perumusan tingkat risiko yang akan diambil (risk appetite) dan toleransi risiko (risk tolerance); dan 2) kecukupan pengawasan aktif oleh Dewan Komisaris dan Direksi termasuk pelaksanaan kewenangan dan tanggung jawab Dewan Komisaris dan Direksi. Dapat dilihat pada Tabel 3. berikut ini:

Tabel 3. Hasil Penilaian Tata Kelola Risiko (Risk Governance) PT. Bank Bengkulu

\begin{tabular}{|c|c|c|c|c|c|}
\hline NO & $\begin{array}{l}\text { KRITERIA DAN } \\
\text { PARAMETER }\end{array}$ & KETERANGAN & $\begin{array}{l}\text { SKOR } \\
1-5\end{array}$ & ВОВОТ & $\begin{array}{c}\text { SKOR } \\
\text { TERBOBOT }\end{array}$ \\
\hline 1 & $\begin{array}{l}\text { Apakah Direksi telah } \\
\text { menetapkan rumusan } \\
\text { tingkat risiko operasional } \\
\text { yang akan diambil (risk } \\
\text { appetite)? }\end{array}$ & $\begin{array}{l}\text { Direksi sudah menetapkan rumusan } \\
\text { tingkat risiko operasional melalui target } \\
\text { write off, target persentase NPL dan } \\
\text { target nasabah macet }\end{array}$ & 3 & 0.02 & 0,07 \\
\hline 2 & $\begin{array}{l}\text { Apakah Direksi telah } \\
\text { menetapkan rumusan } \\
\text { tingkat toleransi risiko } \\
\text { operasional yang akan } \\
\text { diambil (risk tolerance)? }\end{array}$ & $\begin{array}{l}\text { Direksi cukup lengkap menetapkan } \\
\text { rumusan tingkat toleransi risiko } \\
\text { operasional yang akan diambil (risk } \\
\text { tolerance) dgn toleransi batas maksimum } \\
\text { dan minimum, variasi kerugian per } \\
\text { sektor ekonomi yg dibiayai, variasi } \\
\text { besarnya tingkat persentasi NPL, } \\
\text { nasabah macet }\end{array}$ & 3 & 0.02 & 0,07 \\
\hline 3 & $\begin{array}{l}\text { Apakah Dewan Komisaris } \\
\text { secara aktif memberikan } \\
\text { persetujuan terhadap } \\
\text { kebijakan dan strategi } \\
\text { risiko operasional? }\end{array}$ & $\begin{array}{l}\text { Dewan Komisaris aktif memberikan } \\
\text { persetujuan terhadap kebijakan dan } \\
\text { strategi risiko operasional }\end{array}$ & 1 & 0.02 & 0,02 \\
\hline 4 & $\begin{array}{lr}\text { Apakah Dewan Komisaris } \\
\text { secara aktif } & \text { melakukan } \\
\text { evaluasi r r terhadap } \\
\text { eksposur } & \text { risiko } \\
\text { operasional dalam } 3 \text { bulan } \\
\text { terakhir? }\end{array}$ & 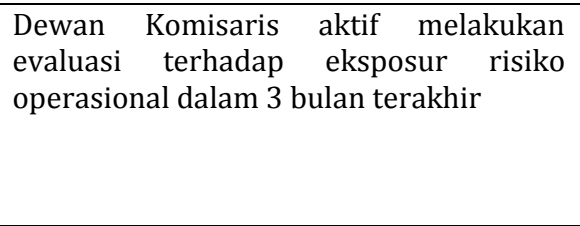 & 1 & 0.02 & 0,02 \\
\hline 5 & 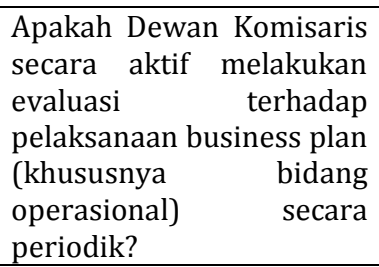 & $\begin{array}{l}\text { Dewan Komisaris aktif melakukan } \\
\text { evaluasi terhadap pelaksanaan business } \\
\text { plan (khususnya bidang operasional) } \\
\text { secara periodik }\end{array}$ & 1 & 0.02 & 0,02 \\
\hline 6 & $\begin{array}{lr}\text { Apakah Dewan Komisaris } \\
\text { secara aktif } & \text { melakukan } \\
\text { evaluasi } & \text { terhadap } \\
\text { implementasi } & \text { kebijakan } \\
\text { dan strategi risiko } & \\
\text { operasional? } & \end{array}$ & $\begin{array}{lcr}\text { Dewan } & \text { Komisaris aktif } & \text { melakukan } \\
\text { evaluasi } & \text { terhadap implementasi } \\
\text { kebijakan dan strategi risiko operasional }\end{array}$ & 1 & 0.02 & 0,02 \\
\hline 7 & $\begin{array}{lr}\text { Apakah Dewan Komisaris } \\
\text { telah mempertimbangkan } \\
\text { toleransi risiko } \\
\text { operasional risk } \\
\text { tolerance) yang ber- } \\
\text { dampak/berpengaruh ter- } \\
\text { hadap permodalan Bank? }\end{array}$ & $\begin{array}{l}\text { Dewan Komisaris mempertimbangkan } \\
\text { toleransi risiko operasional yang } \\
\text { berdampak/berpengaruh terhadap } \\
\text { permodalan Bank }\end{array}$ & 1 & 0.02 & 0,02 \\
\hline 8 & $\begin{array}{l}\text { Apakah Direksi telah } \\
\text { menjabarkan } \\
\text { mengkomunikasikan } \\
\text { kebijakan dan strategi }\end{array}$ & $\begin{array}{lll}\text { belum semua unit kerja menerima dan } \\
\text { memahami strategi risiko yang } \\
\text { dituangkan dalam kebijakan limit yang } \\
\text { berkaitan dengan aktivitas yang }\end{array}$ & 3 & 0.02 & 0,07 \\
\hline
\end{tabular}




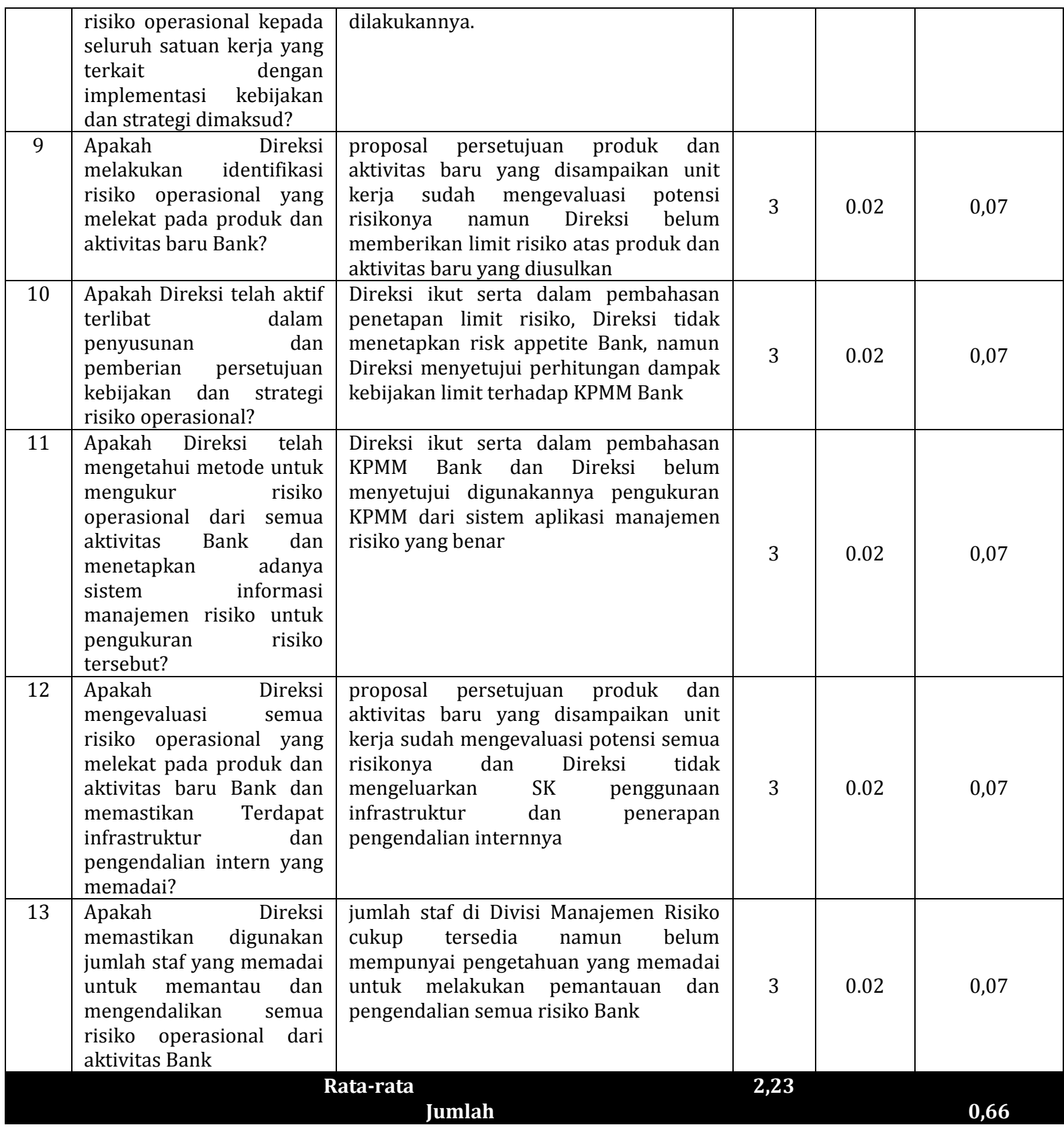

Sumber: PT. Bank Bengkulu, 2013

Keterangan:

Peringkat $1=1,00-1,80=$ Strong

Peringkat $2=1,81-2,60=$ Satisfactory

Peringkat $3=2,61-3,40=$ Fair

Peringkat $4=3,41-4,20=$ Marginal

Peringkat $5=4,21-5,00=$ Unsatisfactory

Dalam isian tentang tata kelola risiko (Risk Governance) PT. Bank Bengkulu yang berhak menjawab adalah komisaris dan direksi PT. Bank Bengkulu. Dari ke 13 pertanyaan tersebut rata-rata jawaban pada skor 2,23 (1,81 - 2,60 = Satisfactory) yaitu Kualitas penerapan manajemen risiko tentang tata kelola risiko (Risk Governance) PT. Bank Bengkulu secara komposit memadai, meskipun terdapat kelemahan minor, tetapi kelemahan tersebut perlu mendapatkan perhatian komisaris dan direksi PT. Bank Bengkulu untuk melakukan perbaikan.

b. Kerangka Manajemen Risiko

Kerangka manajemen risiko mencakup evaluasi terhadap: 1) strategi manajemen risiko yang searah dengan tingkat risiko yang akan diambil dan toleransi risiko; 2) kecukupan perangkat organisasi dalam mendukung terlaksananya manajemen risiko secara efektif termasuk kejelasan wewenang dan tanggung jawab; dan 3) 
kecukupan kebijakan, prosedur dan penetapan limit. Hasil penilaian kerangka manajemen risiko bisa dilihat pada tabel 4. Dibawah ini:

Tabel 4. Hasil Penilaian Kerangka Manajemen Risiko PT. Bank Bengkulu

\begin{tabular}{|c|c|c|c|c|c|}
\hline NO & $\begin{array}{l}\text { KRITERIA DAN } \\
\text { PARAMETER }\end{array}$ & KETERANGAN & $\begin{array}{c}\text { SKOR } \\
1-5\end{array}$ & ВОВОТ & $\begin{array}{c}\text { SKOR } \\
\text { TERBOBOT }\end{array}$ \\
\hline 1 & $\begin{array}{l}\text { Apakah Bank telah memiliki } \\
\text { kebijakan limit risiko } \\
\text { operasional? }\end{array}$ & $\begin{array}{l}\text { terdapat surat keputusan Direksi yang } \\
\text { menguraikan limit risiko untuk semua } \\
\text { jenis risiko yang terperinci baik untuk } \\
\text { limit tiap transaksi, limit kelompok } \\
\text { atau group counterparty, limit } \\
\text { berdasarkan sektor ekonomi, dan limit } \\
\text { keseluruhan eksposur Bank }\end{array}$ & 1 & 0,02 & 0,02 \\
\hline 2 & $\begin{array}{lr}\text { Apakah cakupan } & \text { kebijakan } \\
\text { pengendalian risiko } & \text { rision } \\
\text { operasional telah memadai? }\end{array}$ & $\begin{array}{l}\text { a unit bisnis telah melaksanakan surat } \\
\text { keputusan Direksi tentang limit risiko } \\
\text { untuk semua jenis risiko termasuk } \\
\text { limit untuk tiap transaksi, limit } \\
\text { kelompok atau group counterparty, } \\
\text { limit berdasarkan sektor ekonomi, dan } \\
\text { limit keseluruhan eksposur Bank } \\
\text { namun }\end{array}$ & 3 & 0,02 & 0,07 \\
\hline 3 & $\begin{array}{lr}\text { Apakah } & \text { kebijakan } \\
\text { pengendalian risiko } & \text { rievaluasi dan } \\
\text { operasional dievalu } \\
\text { dikinikan secara periodik } \\
\text { dengan mempertimbangkan } \\
\text { perubahan } & \text { kondisi } \\
\text { pasar,misi dan } & \text { strategi } \\
\text { bisnis. } & \end{array}$ & $\begin{array}{l}\text { Divisi Manajemen Risiko menyusun } \\
\text { laporan tentang realisasi dibanding } \\
\text { kebijakan limit untuk semua jenis } \\
\text { risiko yang terperinci baik untuk limit } \\
\text { tiap transaksi, limit kelompok atau } \\
\text { group counterparty, limit berdasarkan } \\
\text { sektor ekonomi, dan limit keseluruhan }\end{array}$ & 3 & 0,02 & 0,07 \\
\hline 4 & 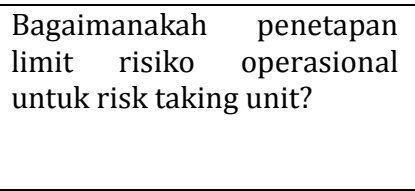 & $\begin{array}{l}\text { Divisi memiliki limit yang meliputi: } \\
\text { limit eksposur per jenis transaksi, limit } \\
\text { per Kantor Cabang/Kantor Cabang } \\
\text { Pembantu, limit pihak terkait, limit } \\
\text { risiko kerugian. }\end{array}$ & 3 & 0,02 & 0,07 \\
\hline 5 & $\begin{array}{lr}\text { Apakah proses penetapan } \\
\text { limit risiko operasional telah } \\
\text { memadai } r \text { dan } \\
\text { didokumentasikan } \\
\text { tertulis }\end{array}$ & 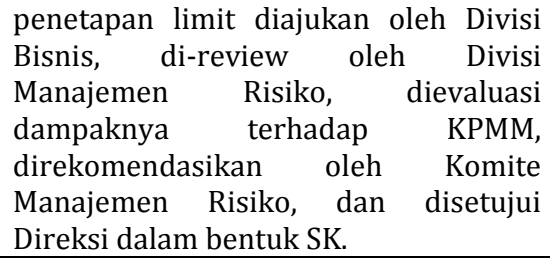 & 1 & 0,02 & 0,02 \\
\hline 6 & $\begin{array}{lr}\text { Apakah } & \text { prosedur } \\
\text { pengendalian } & \text { risiko } \\
\text { operasional telah } & \text { memadai? }\end{array}$ & $\begin{array}{l}\text { realisasi eksposur kredit sesuai dengan } \\
\text { limit, ketentuan BMPK tidak dilanggar, } \\
\text { dan posisi NPL dibawah limit yang } \\
\text { ditetapkan. }\end{array}$ & 3 & 0,02 & 0,07 \\
\hline 7 & $\begin{array}{l}\text { Apakah kebijakan, prosedur, } \\
\text { dan limit risiko operasional } \\
\text { telah di-review dan disetujui } \\
\text { Direksi secara memadai? }\end{array}$ & $\begin{array}{l}\text { kebijakan dan strategi untuk jenis } \\
\text { risiko telah tersedia, prosedur } \\
\text { identifikasi, pengukuran, pemantauan, } \\
\text { dan pengendalian risiko tersedia, dan } \\
\text { limit risiko telah di-review oleh Divisi } \\
\text { Manajemen Risiko, Komite Manajemen } \\
\text { Risiko dan disetujui Direksi }\end{array}$ & 1 & 0,02 & 0,02 \\
\hline 8 & $\begin{array}{l}\text { Apakah kepatuhan terhadap } \\
\text { prosedur pemantauan dan } \\
\text { pengendalian risiko } \\
\text { operasional r sudah } \\
\text { dilaksanakan } \\
\text { memadai? }\end{array}$ & $\begin{array}{l}\text { unit kerja bisnis dan atau Divisi } \\
\text { Manajemen Risiko telah menyusun } \\
\text { laporan realisasi eksposur kredit dan } \\
\text { perbandingannya dengan limit saja }\end{array}$ & 3 & 0,02 & 0,07 \\
\hline \multicolumn{5}{|c|}{$\begin{array}{l}\text { Rata-rata } \\
\text { Jumlah Skor Terbobot }\end{array}$} & 0,41 \\
\hline
\end{tabular}

Sumber: PT. Bank Bengkulu, 2013

Keterangan:

Peringkat $1=1,00-1,80=$ Strong

Peringkat $2=1,81-2,60=$ Satisfactory

Peringkat $3=2,61-3,40=$ Fair
Peringkat $4=3,41-4,20=$ Marginal

Peringkat $5=4,21-5,00=$ Unsatisfactory 
Dalam isian tentang kerangka manajemen risiko PT. Bank Bengkulu yang berhak menjawab adalah Kepala Divisi PT. Bank Bengkulu. Dari ke 8 pertanyaan tersebut rata-rata jawaban pada skor 2,25 (1,81 - 2,60 = Satisfactory $)$ yaitu Kualitas penerapan manajemen risiko tentang kerangka manajemen risiko PT. Bank Bengkulu secara komposit memadai, meskipun terdapat kelemahan minor, tetapi kelemahan tersebut perlu mendapatkan perhatian komisaris dan direksi PT. Bank Bengkulu untuk melakukan perbaikan.

c. Proses Manajemen Risiko

Proses manajemen risiko kecukupan Sumber Daya Manusia, dan kecukupan sistem informasi manajemen risiko mencakup evaluasi terhadap: 1) proses identifikasi, pengukuran, pemantauan, dan pengendalian Risiko; 2) kecukupan sistem informasi manajemen risiko; dan 3) kecukupan kuantitas dan kualitas sumber daya manusia dalam mendukung efektivitas proses manajemen risiko. Hasil penilaian proses manajemen risiko bisa dilihat pada tabel 5. Dibawah ini:

Tabel 5. Hasil Penilaian Proses Manajemen Risiko PT. Bank Bengkulu

\begin{tabular}{|c|c|c|c|c|c|}
\hline NO & KRITERIA DAN PARAMETER & KETERANGAN & $\begin{array}{c}\text { SKOR } \\
1-5\end{array}$ & ВОВОТ & $\begin{array}{c}\text { SKOR } \\
\text { TERBOBOT }\end{array}$ \\
\hline 1 & $\begin{array}{llr}\text { Apakah proses identifikasi } \\
\text { risiko operasional telah } \\
\text { memadai? }\end{array}$ & $\begin{array}{l}\text { identifikasi risiko atas transaksi pemberian } \\
\text { kredit dan penyaluran dana investasi treasuri } \\
\text { antar bank. }\end{array}$ & 3 & 0,02 & 0,07 \\
\hline 2 & $\begin{array}{l}\text { Apakah pengukuran risiko } \\
\text { operasional telah memadai? }\end{array}$ & $\begin{array}{l}\text { pengukuran risiko operasional dilakukan } \\
\text { dengan pendekatan standar atau IRB dan hanya } \\
\text { mencakup semua eksposur kredit. }\end{array}$ & 3 & 0,02 & 0,07 \\
\hline 3 & $\begin{array}{l}\text { Apakah Bank } r \text { melakukan } \\
\text { pemantauan risiko operasional? }\end{array}$ & $\begin{array}{lcrr}\text { pemantauan } & \text { terhadap } & \text { risiko operasional } \\
\text { mencakup tendensi } & \text { perubahan } & \text { kualitas } \\
\text { pinjaman, keadaan } & \text { keuangan } & \text { setiap } \\
\text { counterparty, kecukupan jaminan relatif } & \text { reman } \\
\text { terhadap nilai kredit pengelompokkan dan } \\
\text { pemantauan NPL. }\end{array}$ & 3 & 0,02 & 0,07 \\
\hline 4 & $\begin{array}{llr}\text { Apakah } & \text { cakupan } & \text { sistem } \\
\text { informasi } & \text { manajemen } & \text { risiko } \\
\text { operasional telah memadai? }\end{array}$ & $\begin{array}{l}\text { SIM risiko memberikan informasi tentang } \\
\text { laporan KPMM, laporan profil risiko, laporan } \\
\text { trend profil risiko, laporan produk dan aktivitas } \\
\text { kredit baru, laporan lainnya yang diminta } \\
\text { Direksi. }\end{array}$ & 3 & 0,02 & 0,07 \\
\hline 5 & $\begin{array}{l}\text { Apakah laporan pengendalian } \\
\text { risiko operasional telah } \\
\text { disampaikan tepat waktu } \\
\text { kepada Direksi }\end{array}$ & $\begin{array}{l}\text { laporan yang dihasilkan oleh SIM risiko belum } \\
\text { mencakup semua kebutuhan informasi untuk } \\
\text { pengelolaan risiko, informasi tersebut } \\
\text { dilaporkan pada waktunya, namun manajemen } \\
\text { belum mempergunakan laporan tersebut untuk } \\
\text { dasar pengambilan keputusan pengelolaan risi }\end{array}$ & 3 & 0,02 & 0,07 \\
\hline 6 & $\begin{array}{l}4 \text { Apakah asumsi utama, sumber } \\
\text { data, dan prosedur yang } \\
\text { digunakan untuk mengukur dan } \\
\text { memantau risiko operasional } \\
\text { telah layak dan dianalisis secara } \\
\text { memadai dan } \\
\text { didokumentasikan dan apakah } \\
\text { terdapat sistem untuk } \\
\text { melakukan pengujian } \\
\text { realibilitasnya secara berkela }\end{array}$ & $\begin{array}{l}\text { terdapat dokumentasi atas penggunaan asumsi } \\
\text { utama, uraian sumber data, dan prosedur yang } \\
\text { digunakan dan analisisnya namun tidak } \\
\text { terdapat sistem untuk melakukan pengujian } \\
\text { realibilitasnya secara berkelanjutan }\end{array}$ & 3 & 0,02 & 0,07 \\
\hline 7 & $\begin{array}{l}\text { Apakah terhadap perubahan } \\
\text { produk dan aktivitas business } \\
\text { line Bank melakukan } \\
\text { perubahan sistem pengukuran } \\
\text { dan pemantauan yang } \\
\text { memadai? }\end{array}$ & $\begin{array}{l}\text { terdapat dokumentasi atas analisis perubahan } \\
\text { produk, aktivitas dan penggunaan sistem untuk } \\
\text { pengukuran namun belum ada perubahan } \\
\text { pemantauan risikonya }\end{array}$ & 3 & 0,02 & 0,07 \\
\hline 8 & $\begin{array}{l}\text { Apakah laporan SIM risiko } \\
\text { konsisten dengan aktivitas } \\
\text { Bank dan distruktur untuk } \\
\text { memantau semua eksposur, } \\
\text { kepatuhan terhadap limit, } \\
\text { tujuan, perbandingan antara } \\
\text { kinerja yang diharapkan dan } \\
\text { realisasinya secara memadai? }\end{array}$ & $\begin{array}{l}\text { laporan SIM risiko yang dihasilkan dapat } \\
\text { digunakan untuk memantau semua eksposur, } \\
\text { kepatuhan terhadap limit, dan tujuan }\end{array}$ & 3 & 0,02 & 0,07 \\
\hline 9 & $\begin{array}{l}\text { Apakah laporan } \quad \text { Sistem } \\
\text { Informasi Manajemen (SIM) } \\
\text { risiko untuk memantau semua } \\
\text { eksposur, kepatuhan terhadap } \\
\text { limit, tujuan, perbandingan }\end{array}$ & $\begin{array}{l}\text { laporan SIM risiko yang dihasilkan hanya } \\
\text { disampaikan kepada Dewan Komisaris dan } \\
\text { Direksi sesuai dengan wewenang dan tanggung } \\
\text { jawabnya. }\end{array}$ & 3 & 0,02 & 0,07 \\
\hline
\end{tabular}




\begin{tabular}{|c|c|c|c|c|c|}
\hline & $\begin{array}{l}\text { antara kinerja yang diharapkan } \\
\text { dan realisasinya didistribusikan } \\
\text { secara memadai? }\end{array}$ & & & & \\
\hline 10 & $\begin{array}{l}\text { Apakah laporan SIM risiko } \\
\text { untuk memantau semua } \\
\text { eksposur, kepatuhan terhadap } \\
\text { limit, tujuan, perbandingan } \\
\text { antara kinerja yang diharapkan } \\
\text { dan realisasinya didistribusikan } \\
\text { secara akurat, tepat waktu, dan } \\
\text { berisi informasi bagi pengambil } \\
\text { keputusan untuk mengide }\end{array}$ & $\begin{array}{l}\text { laporan SIM risiko yang dihasilkan belum dapat } \\
\text { digunakan untuk memantau semua eksposur, } \\
\text { kepatuhan terhadap limit, tujuan, dan } \\
\text { perbandingan antara kinerja yang diharapkan } \\
\text { dan realisasinya, namun tepat waktu }\end{array}$ & 3 & 0,02 & 0,07 \\
\hline 11 & $\begin{array}{l}\text { Apakah laporan SIM risiko } \\
\text { berisi informasi remua } \\
\text { peringkat risiko operasional } \\
\text { yang dihadapi Bank dan } \\
\text { dilakukan evaluasi secara } \\
\text { memadai? }\end{array}$ & $\begin{array}{l}\text { laporan SIM risiko yang dihasilkan dapat } \\
\text { digunakan untuk memantau semua eksposur, } \\
\text { kepatuhan terhadap limit, tujuan, dan } \\
\text { perbandingan antara kinerja yang diharapkan } \\
\text { dan realisasinya, dan dievaluasi dan tidak } \\
\text { dilaporkan kepada Dewan Komisaris, Direksi, } \\
\text { dan }\end{array}$ & 3 & 0,02 & 0,07 \\
\hline \multicolumn{5}{|c|}{ Rata-rata } & \\
\hline
\end{tabular}

Sumber: PT. Bank Bengkulu, 2013

Keterangan:

Peringkat $1=1,00-1,80=$ Strong

Peringkat $2=1,81-2,60=$ Satisfactory

Peringkat $4=3,41-4,20=$ Marginal

Peringkat $3=2,61-3,40=$ Fair

Peringkat $5=4,21-5,00=$ Unsatisfactory

Dalam isian tentang proses manajemen risiko PT. Bank Bengkulu. Dari ke 11 pertanyaan tersebut rata-rata jawaban pada skor 3,00 $(2,61$ - 3,40 = Fair $)$ yaitu Kualitas penerapan manajemen risiko secara komposit cukup memadai, terdapat beberapa kelemahan, yang membutuhkan perhatian manajemen dan perbaikan.

d. Sistem Pengendalian Risiko

Kecukupan sistem pengendalian risiko mencakup evaluasi terhadap: 1) kecukupan Sistem Pengendalian Intern; dan 2) kecukupan kaji ulang oleh pihak independen (independent review) dalam bank baik oleh Satuan Kerja Manajemen Risiko (SKMR) maupun oleh Satuan Kerja Audit Intern (SKAI). Kaji ulang oleh SKMR antara lain: mencakup metode, asumsi, dan variabel yang digunakan untuk mengukur dan menetapkan limit Risiko, sedangkan kaji ulang oleh SKAI antara lain: mencakup keandalan kerangka manajemen risiko dan penerapan manajemen risiko oleh unit bisnis dan/atau unit pendukung. Hasil penilaian sistem pengendalian risiko bisa dilihat pada tabel 6. Dibawah ini:

\section{Tabel 6. Hasil Penilaian Sistem Pengendalian Risiko PT. Bank Bengkulu}

\begin{tabular}{|c|c|c|c|c|c|}
\hline NO & KRITERIA DAN PARAMETER & KETERANGAN & $\begin{array}{l}\text { SKOR } \\
1-5\end{array}$ & BOBOT & $\begin{array}{c}\text { SKOR } \\
\text { TERBOBOT }\end{array}$ \\
\hline 1 & $\begin{array}{l}\text { Apakah struktur organisasi } \\
\text { manajemen risiko yang dimiliki } \\
\text { Bank telah menggambarkan } \\
\text { batas wewenang dan tanggung } \\
\text { jawab manajemen risiko } \\
\text { operasional yang jelas? }\end{array}$ & $\begin{array}{l}\text { Terdapat SK yang memberikan struktur } \\
\text { organisasi dengan uraian batasan } \\
\text { wewenang dan tanggung jawab secara } \\
\text { tertulis, namun blm mencakup semua unit } \\
\text { kerja terkait. }\end{array}$ & 1 & 0,02 & 0,02 \\
\hline 2 & 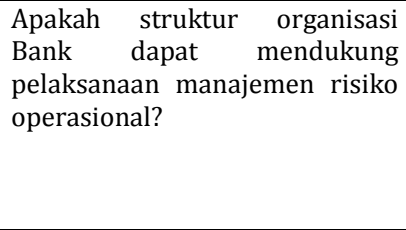 & 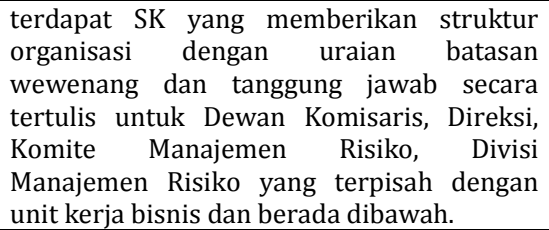 & 1 & 0,02 & 0,02 \\
\hline 3 & $\begin{array}{l}\text { Apakah terdapat pemisahan } \\
\text { fungsi yang jelas antara satuan } \\
\text { kerja operasional (business } \\
\text { unit) dengan satuan kerja yang } \\
\text { melaksanakan fungsi } \\
\text { pengendalian intern? }\end{array}$ & $\begin{array}{l}\text { terdapat SK yang memberikan struktur } \\
\text { organisasi dengan DAI, Divisi Manajemen } \\
\text { Risiko, Divisi Teknologi Informasi / } \\
\text { Kepatuhan? terpisah dengan unit kerja } \\
\text { bisnis serta Divisi Manajemen Risiko berada } \\
\text { dibawah Direktur yang berbeda dengan } \\
\text { Direktur yang membawah }\end{array}$ & 1 & 0,02 & 0,02 \\
\hline 4 & $\begin{array}{l}\text { Apakah kewenangan untuk } \\
\text { mengakses, memodifikasi dan }\end{array}$ & $\begin{array}{l}\text { terdapat SK Direksi yang mengatur tentang } \\
\text { kewenangan untuk mengakses, }\end{array}$ & 3 & 0,02 & 0,07 \\
\hline
\end{tabular}




\begin{tabular}{|c|c|c|c|c|c|}
\hline & $\begin{array}{l}\text { merubah model pengukuran } \\
\text { risiko operasional dan software } \\
\text { MIS-nya telah dibatasi hanya } \\
\text { pada pejabat yang berwenang? }\end{array}$ & $\begin{array}{l}\text { memodifikasi, dan merubah model } \\
\text { pengukuran risiko dan software MIS-nya } \\
\text { namun tidak dibatasi hanya pada pejabat } \\
\text { yang berwenang saja. }\end{array}$ & & & \\
\hline 5 & $\begin{array}{l}\text { Apakah transaksi dan aktivitas } \\
\text { fungsional yang mempunyai } \\
\text { eksposur risiko operasional } \\
\text { telah disetujui oleh pejabat yang } \\
\text { berwenang? }\end{array}$ & $\begin{array}{l}\text { terdapat SK Direksi tentang ketentuan limit } \\
\text { eksposur risiko, namun limit eksposur } \\
\text { risiko tersebut belum dirinci untuk setiap } \\
\text { jenjang jabatan. }\end{array}$ & 3 & 0,02 & 0,07 \\
\hline 6 & $\begin{array}{l}\text { Apakah transaksi dan aktivitas } \\
\text { fungsional yang mempunyai } \\
\text { eksposur risiko operasional } \\
\text { telah direview dan dipantau } \\
\text { oleh masing-masing unit bisnis? }\end{array}$ & $\begin{array}{l}\text { tiap unit bisnis terkait belum melakukan } \\
\text { pemantauan terhadap semua eksposur } \\
\text { risiko operasional yang mencakup tendensi } \\
\text { perubahan kualitas pinjaman, keadaan } \\
\text { keuangan setiap counterparty, kecukupan } \\
\text { jaminan relatif terhadap nilai kredit } \\
\text { pengelompokkan dan pem }\end{array}$ & 3 & 0,02 & 0,07 \\
\hline 7 & $\begin{array}{l}\text { Apakah telah dilaksanakan audit } \\
\text { secara berkala oleh internal } \\
\text { auditor untuk menilai } \\
\text { pelaksanaan, proses dan sistem } \\
\text { manajemen risiko operasional } \\
\text { pada aktivitas fungsional yang } \\
\text { memiliki eksposur risiko serta } \\
\text { dilakukan tindak lanjut atas } \\
\text { temuan pemeriksaan? }\end{array}$ & $\begin{array}{l}\text { internal auditor sudah melakukan audit } \\
\text { yang meliputi Pengawasan aktif Dewan } \\
\text { Komisaris dan Direksi, kecukupan kebijakn } \\
\text { dan prosedur serta limit risiko, kecukupan } \\
\text { sistem informasi manajemen risiko, dan } \\
\text { kecukupan pengendalian intern atas } \\
\text { penerapan manajemen r }\end{array}$ & 3 & 0,02 & 0,07 \\
\hline 8 & $\begin{array}{l}\text { Apakah sistem pengendalian } \\
\text { intern cocok atau sesuai untuk } \\
\text { jenis dan level risiko } \\
\text { operasional yang ditanggung } \\
\text { sesuai dengan sifat dan lingkup } \\
\text { aktivitas bisnis Bank? }\end{array}$ & $\begin{array}{l}\text { sistem pengendalian intern baru mengatur } \\
\text { tentang pemahaman manajemen dan } \\
\text { budaya pengendalian, penilaian risiko, } \\
\text { aktivitas pengendalian dan aktivitas } \\
\text { pemantauan untuk semua jenis risiko yang } \\
\text { ditanngung Bank }\end{array}$ & 3 & 0,02 & 0,07 \\
\hline 9 & $\begin{array}{l}\text { Apakah laporan-laporan } \\
\text { keuangan dan operasional } \\
\text { adalah akurat, dapat dipercaya, } \\
\text { dan tepat waktu dan apakah jika } \\
\text { terdapat penyimpangan segera } \\
\text { dilakukan penelitian dan } \\
\text { perbaikannya? }\end{array}$ & $\begin{array}{l}\text { laporan audit yang dihasilkan sudah } \\
\text { memeriksa semua eksposur, kepatuhan } \\
\text { terhadap limit, tujuan, dan perbandingan } \\
\text { antara kinerja yang diharapkan dan } \\
\text { realisasinya, dan dievaluasi namun belum } \\
\text { dilaporkan kepada Dewan Komisaris, } \\
\text { Direksi, dan Komite Manajemen R }\end{array}$ & 3 & 0,02 & 0,07 \\
\hline 10 & $\begin{array}{l}\text { Apakah terdapat prosedur yang } \\
\text { memadai untuk memastikan } \\
\text { Terdapat kepatuhan terhadap } \\
\text { peraturan, undang-undang, dan } \\
\text { kebijakan serta prosedur } \\
\text { internal? }\end{array}$ & $\begin{array}{l}\text { prosedur audit belum sepenuhnya dapat } \\
\text { digunakan memeriksa semua eksposur, } \\
\text { kepatuhan terhadap limit, tujuan, dan } \\
\text { perbandingan antara kinerja yang } \\
\text { diharapkan dan realisasinya, serta belum } \\
\text { semua prosedur memenuhi ketentuan } \\
\text { semua peraturan, undang-undang, dan }\end{array}$ & 3 & 0,02 & 0,07 \\
\hline 11 & $\begin{array}{l}\text { Apakah prosedur audit intern } \\
\text { memberikan kecukupan lingkup } \\
\text { pemeriksaan operasional Bank } \\
\text { dan bersifat independen dan } \\
\text { obyektif? }\end{array}$ & $\begin{array}{l}\text { prosedur audit telah berbasis risiko untuk } \\
\text { memeriksa semua eksposur, kepatuhan } \\
\text { terhadap limit, tujuan, dan perbandingan } \\
\text { antara kinerja yang diharapkan dan } \\
\text { realisasinya, memenuhi ketentuan semua } \\
\text { peraturan, undang-undang, dan kebijakan } \\
\text { intern serta bersifat }\end{array}$ & 1 & 0,02 & 0,02 \\
\hline 12 & $\begin{array}{l}\text { Apakah sistem informasi dan } \\
\text { pengendalian intern memadai } \\
\text { dan cukup direview serta di-test } \\
\text { dan apakah respon manajemen } \\
\text { terhadap audit } \\
\text { didokumentasikan arara } \\
\text { memadai? }\end{array}$ & $\begin{array}{l}\text { sistem informasi dan pengendalian intern } \\
\text { belum memberikan semua informasi atas } \\
\text { audit risiko eksposur, kepatuhan terhadap } \\
\text { limit, tujuan, dan perbandingan antara } \\
\text { kinerja yang diharapkan dan respon } \\
\text { manajemen belum tepat waktu atau belum } \\
\text { didokumentasikan. }\end{array}$ & 3 & 0,02 & 0,07 \\
\hline 13 & $\begin{array}{l}\text { Apakah kelemahan yang } \\
\text { material dan telah diidentifikasi } \\
\text { diberikan respon secara tepat } \\
\text { waktu dan memadai dan apakah } \\
\text { respon tersebut secara obyektif } \\
\text { diverifikasi dan direview secara } \\
\text { memadai? }\end{array}$ & $\begin{array}{l}\text { laporan respon/tindak lanjut kelemahan } \\
\text { material oleh Unit Kerja yang diaudit } \\
\text { dilakukan kurang dari } 1 \text { bulan dan terdapat } \\
\text { verifikasi serta review DAI atas respon } \\
\text { tersebut. }\end{array}$ & 1 & 0,02 & 0,02 \\
\hline & \multicolumn{2}{|c|}{$\begin{array}{l}\text { Rata-rata } \\
\text { Jumlah Skor Terbobot }\end{array}$} & & & 0,66 \\
\hline
\end{tabular}

Sumber: PT. Bank Bengkulu, 2013

Keterangan:

Peringkat $1=1,00-1,80=$ Strong

Peringkat $2=1,81-2,60=$ Satisfactory

Peringkat $3=2,61-3,40=$ Fair

Peringkat $4=3,41-4,20=$ Marginal

Peringkat $5=4,21-5,00=$ Unsatisfactory 
Dalam isian tentang system pengendalian risiko PT Bank Bengkulu, nelalui 13 pertanyan/parameter tersebut rata-rata jawaban pada skor 2,23 (1,81 - 2,60 = Satisfactory $)$ yaitu kualitas penerapan manajemen risiko pada PT Bank Bengkulu dikategorikan secara komposit memadai, meskipun terdapat kelemahan minorm tetapi kelemahan tersebut perlu mendapatkan perhatian manajemen Bank Bengkulu untuk melakukan perbaikan. bawah ini :

Hasil perhitungan di atas memiliki matrik peringkat risiko seperti pada tabel 7. di

Tabel 7. Matrik Peringkat Risiko PT. Bank Bengkulu

\begin{tabular}{|c|c|c|c|c|c|}
\hline Risiko Inheren & Strong & Satisfactory & Fair & Marginal & Unsatisfactory \\
\hline Low & & & & & \\
\hline Low to Moderate & & 2.50 & & & \\
\hline Moderate & & & & & \\
\hline Moderate to High & & & & & \\
\hline High & & & & & \\
\hline
\end{tabular}

Sumber: PT. Bank Bengkulu, 2013

Keterangan:

Peringkat $1=1,00-1,80=$ Strong $\quad$ Peringkat $4=3,41-4,20=$ Marginal

Peringkat $2=1,81-2,60=$ Satisfactory $\quad$ Peringkat $5=4,21-5,00=$ Unsatisfactory

Peringkat $3=2,61-3,40=$ Fair

\section{Pembahasan}

Hasil penelitian diperoleh bahwa penerapan manajemen risiko di PT. Bank Bengkulu secara rata-rata nilainya 2,50 berada pada interval 1,81-2,60 dengan kriteria Satisfactory. Hasil kriteria dan parameter penilaian penerapan manajemen risiko di PT. Bank Bengkulu secara menyeluruh dapat dilihat pada tabel 8. Berikut ini:

\section{Tabel 8. Hasil Penilaian Manajemen Risiko PT. Bank Bengkulu}

\begin{tabular}{|c|l|c|c|}
\hline NO & \multicolumn{1}{|c|}{ KRITERIA DAN PARAMETER } & Kriteria \\
\hline 1 & Tata Kelola Risiko (Risk Governance) & 0,66 & \\
\hline 2 & Kerangka Manajemen Risiko & 0,41 \\
\hline 4 & Proses Manajemen Risiko & 0,77 \\
\hline & Sistem Pengendalian Risiko & 0,66 & \\
\hline & Jumlah & $\mathbf{2 , 5 0}$ & \multirow{2}{*}{ Satisfactory } \\
\hline
\end{tabular}

Sumber: PT. Bank Bengkulu, 2013

Keterangan:

Peringkat $1=1,00-1,80=$ Strong

Peringkat $2=1,81-2,60=$ Satisfactory

Peringkat $3=2,61-3,40=$ Fair

Peringkat $4=3,41-4,20=$ Marginal

Peringkat $5=4,21-5,00=$ Unsatisfactory

\section{Penjelasan Peringkat :}

- Peringkat 1 (Strong): Kualitas penerapan manajemen risiko secara komposit sangat memadai, meskipun terdapat kelemahan minor, tetapi kelemahan tersebut dapat diabaikan.

- Peringkat 2 (Satisfactory): Kualitas penerapan manajemen risiko secara komposit memadai, meskipun terdapat kelemahan minor, tetapi kelemahan tersebut perlu mendapatkan perhatian manajemen.

- Peringkat 3 (Fair): Kualitas penerapan manajemen risiko secara komposit cukup memadai, terdapat beberapa kelemahan, yang membutuhkan perhatian manajemen dan perbaikan. 
- Peringkat 4 (Marginal): Kualitas penerapan manajemen risiko secara komposit kurang memadai, terdapat kelemahan signifikan pada berbagai aspek manajemen risiko yang membutuhkan tindakan korektif segera.

- Peringkat 5 (Unsatisfactory): Kualitas penerapan manajemen risiko secara komposit tidak memadai, terdapat kelemahan signifikan minor, tetapi kelemahan tersebut dapat diabaikan.

Berdasarkan hal di atas dapat dijelaskan bahwa sesuai degan pedoman dari Bank Indonesia, setiap tiga bulan Bank Bengkulu melakukan assessment terhadap profil risiko secara keseluruhan, penilaian terhadap manajemen risiko ditentukan dengan menggabungkan hasil penilaian eksposur risiko yang melekat (inherent risk) dan kecukupan system pengendalian risiko (risk control system), yang meliputi :

- Pengawasan aktif Dewan komisaris dan Direksi Bank

- Kecukupan Kebijakan, prosedur dan penetapan Limit

- Kecukupan Identifikasi, pengukuran, Pemantauan dan Sistem Informasi Manajemen Risiko

- Sistem Pengendalian Intern Yang Komprehensif

Penerapan Manajemen Risiko dalam dunia perbankan di Indonesia merupakan suatu keharusan dengan tujuan agar setiap potensi risiko yang akan timbul di masa mendatang dapat diidentifikasi, dikelola dan dikendalikan seminimal mungkin. Situasi lingkungan internal dan eksternal bank yang berkembang pesat yang diikuti denggan semakin kompleknya risiko kegiatan usaha sehingga meningkatan kebutuhan praktek tata kelola bank yang sehat (good corporate governance) dan penerapan manajemen risiko. Sesuai dengan Peraturan bank Indonesia (PBI) Nomor 5/8/2003 tanggal 19 Mei 2003 sebagaimana telah diubah dengan Peraturan bank Indonesia (PBI) Nomor 11/25/PBI/2009 tentang Penerapan Manajemen Risiko bagi Bank Umum. Bank Bengkulu telah menetapkan langkah strategis dan terintegrasi dalam persiapan penerapan Basel II. Berbagai langkah yang telah dilakukan Bank Bengkulu dalam mempersiapkan penerapan Basel II sesuai dengan ketentuan yang berlaku berupa kajian terhadap pentingnya risio serta menciptakan budaya risiko (risk culture) pada setiap unit kerja. Sebagai lembaga keuangan yang merupakan lembaga kepercayaan masyarakat dan sebagai lembaga intermediasi dalam pengelolaan risiko usaha, Bank bengkulu senantiasa mengacu kepada kepentingan strategis Bank dan prinsip kehati-hatian, tidak memihak kepada satu kepentingan tertentu, meminimalkan risiko, melakukan upaya deteksi dini (early warning system) atas risiko yang terjadi.

Penerapan manajemen risiko menuntut dilakukannya perubahan-perubahan organisasi, seperti: penyesuaian organisasi bank, perumusan kebijakan dan strategi baru yang disesuaikan dengan Basel II Framework, penyiapan sumber daya manusia, penerapan metodologi baru terutama yang berkaitan dengan identifikasi, pengukuran dan pemantauan risiko yang mengacu pada penyempurnaan Teknologi Sistem informasi termasuk system perbankan yang telah beroperasi saat ini. Untuk itu Bank bengkulu telah membuat suatu pedoman mengenai Manajemen Risiko terdiri dari kebijakan dan prosedur manajemen risiko kredit, risiko pasar, risiko operasional, risiko likuiditas, risiko strategic, risiko reputasi, risiko kepatuhan dan risiko hukum, dan pedoman penyusunan profit risiko serta pedoman strategi dan limit risiko.

kinerja guna menghadapi persaingan dunia perbankan yang semakin kompetitif dengan tetap mempertahankan prinsip prudent banking, professional dan independen, sesuai dalam visi dan misi Bank Bengkulu.

Bank Bengkulu telah menetapkan strategi yang dituangkan dalam Rencana Binis Bank secara berkelanjutan untuk mencapai sasaran, antara lain : 1) melakukan pendekatan kepada seluruh pemegang saham untuk konsisten mendukung rencana penambahan setoran modal, meningkatkan penghimpunan dana pihak ketiga dari masyarakat, menerapkan prinsip prudential banking dalampenyaluran kredit, memotong jalur birokrasi yang panjang dengan sistem pelayanan yang cepat, terpadu dengan didukung oleh sistem online yang terintegrasi, penataan struktur organisasi sesuai kompleksitas usaha serta mengantisipasi kemungkinan tingkat persaingan yang makin kompetitif dan kebutuhan operasional yang kompleks, meningkatkan kualitas sumber daya manusia Bank Bengkulu melalui pelatihan dan pendidikan secara terprogram dan terstruktur, sehingga akanmenghasilkan SDM yang handal dan mampu bersaing dengan bank-bank lain, 2) penetapan kebijakan manajemen risiko bank dengan cara 
menyusun strategi manajemen risiko, yang bisa memastikan bahwa Bank Bengkulu tetap mempertahankan eksposur risiko yang sesuai dengan kebijakan, prosedur intern bank, peraturan perundang-undangan dan ketentuan lain yang berlaku, dan pengelolaan risiko bank oleh sumber daya manusia yang memiliki pengetahuan, pengalaman, dan keahlian di bidang manajemen risiko, sesuai dengan kompleksitas dan kemampuan usaha Bank Bengkulu, sehingga strategi yang ditetapkan Bank Bengkulu adalah dengan meminimalisir potensi terjadinya risiko yang akan dihadapi Bank (preemptive action); dan 3) pengembangan infrastruktur, pengembangan jaringan komunikasi di lingkungan Bank Bengkulu, pengembangan aplikasi utama core banking system melalui pengembangan aplikasi sesuai dengan kebutuhan, pengembangan aplikasi trade finance, pengembangan aplikasi treasury, peningkatan data sistem, pembangunan lanjutan data warehouse, pengembangan aplikasi managemen risiko, pengembangan aplikasi monitoring kinerja bank, jaringan produk baru. dan pengembangan delivery channel. Dengan ketiga strategi tersebut di atas dapat disimpulkan bahwa implementasi manajemen risiko pada Bank Bengkulu termasuk dalam kategori cukup baik. (Sumber: Laporan Tahunan PT Bank Bengkulu, 2012)

\section{Kesimpulan}

Dari hasil penelitian dapat penulis kemukakan beberapa kesimpulan sebagai berikut ;

1. Penerapan manajemen risiko di PT. Bank Bengkulu secara rata-rata nilainya 2,50 berada pada interval 1,81-2,60 dengan kriteria Satisfactory.

2. Penilaian terhadap kualitas implementasi manajemen risiko pada PT Bank Bengkulu dapat ditelusuri dari tahapan-tahapan penyusunan strategi, program, kebijakan, sasaran, dan implementasinya.

\section{Saran}

1. Manajemen Bank Bengkulu sebaiknya terus melakukan evaluasi dan pengkinian terhadap kebijakan-kebijakan dan peraturan-peraturan yang tidak layak atau tidak sesuai lagi dengan kondisi bisnis bank saat ini.

2. Bank Bengkulu harus mulai berbenah atau paling tidak mempertahankan hasil dari penilaian profil risiko yang menunjukkan predikat rendah risiko dan memiliki tingkat pengendalian yang kuat, agar dapat memitigasi risiko di masa mendatang

3. Menanamkan budaya sadar risiko di kalangan karyawan Bank Bengkulu secara kontinyu dengan memberikan pemahaman yang memadai mengenai faktor-faktor risiko yang terkait dengan pekerjaan atau fungsinya sehari-hari.

4. Terus melakukan pengembangan dan penyempurnaan aplikasi dan system Tekhnologi Informasi, mengingat semakin berkembangnya kebutuhan akan tekhnologi yang menunjang kondisi bisnis perbankan, sehingga Bank Bengkulu dapat terus berkompetisi dalam memberikan pelayanan yang prima terhadap nasabah-nasabahnya.

\section{DAFTAR PUSTAKA}

Hanip, 2011, Analisis Manajemen Risiko Pembiayaan Tanpa Agunan UMKM, Univeristas Islam Negeri Maulana Malik Ibrahim, Malang

Hasibuan, S.P, Melayu. 2007. Dasar - Dasar Perbankan. Bumi Aksara, Jakarta.

Kasmir. 2005. Manajemen Perbankan. PT Raja Grafindo Persada, Jakarta. 2013. Bank dan Lembaga keuangan Lainnya. PT Raja Grafindo Persada, Jakarta.

Komarudin, Sastradipoera, 2004, Strategi Manajemen Bisnis Perbankan, Konsep dan Implementasi untuk Bersaing, Kappa-Sigma, Bandung 
Kuncoro dan Suhardjono, 2002, Manajemen Perbankan (Teori dan Aplikasi), Edisi Pertama, Penerbit BPFE, Yogyakarta.

Moleong, Lexi J. 2004. Metodologi Penelitian Kualitatif. PT. Remaja Rosdakarya, Bandung.

Nazir Moh, 2007. Metode Penelitian, Ghalia Indonesia, Jakarta

Nandhifah, 2008, Analisis Manajemen Risiko Kredit Umum Pedesaan dengan Bantuan Simulasi Program Komputer BRI unit Ciampea Bogor, Univeristas Diponegoro, Semarang

Pandia, Frianto, 2012, Manajemen Dana Dan Kesehatan Bank, Rineka Cipta, Jakarta.

Peraturan Bank Indonesia (PBI) No.11/25/PBI/2009 Tertanggal 1 Juli2009

Peraturan Bank Indonesia (PBI) No.5/8/PBI/2003. Tanggal 19 Mei 2003.

Peraturan Bank Indonesia (PBI) No.7/2/PBI/2005 Tertanggal 20 januari 2005

Rachmat Firdaus dan Maya Ariyanti, 2004, Manajemen Perkreditan Bank Umum, Edisi Dua. Alfabeta, Bandung

Soehatman Ramli, 2010, Sistem Manajemen Keselamatan dan Kesehatan Kerja (OHSAS 18001), Seri Manajemen K3, PT. Dian Rakyat, Jakarta

Sugiyono, 2011, Metode Penelitian Pendidikan (pendekatan kuantitatif, kualitatif, dan R\&D, Alfabeta, Bandung

Sunyoto, Danang, 2011, Praktik SPSS Untuk Kasus, Nuha Medika, Yogyakarta

Surat Ederan Bank Indonesia No.5/21/DPNP Tanggal 29 September 2003.

Surat Keputusan Direksi Bank Bengkulu No.100/HP.00.02.03/D.9/2011 Tanggal 25 Nopember 2011.

Suryabrata, Sumadi, 2009. Metodologi Penelitian. PT. Raja Grafindo Persada, Jakarta.

Susilo, S.Y dkk. 2000. Bank dan Lembaga Keuangan Lainnya. Salemba Empat, Jakarta.

Taswan. 2006. Manajemen Perbankan. Cetakan Pertama. YKPN, Yogyakarta.

Undang - Undang Nomor 10. Tahun 1998 Tentang Perbankan.

Undang - Undang Nomor 7. Tahun 1992 Tentang Perbankan.

W. Gulo, 2010. Metodologi Penelitian. PT. Gramedia, Jakarta.

Veithzal, Rivai dan Andria Permata Veithzal. 2006. Credit Management Handbook. Edisi Pertama. PT Raja Grafindo Persada, Jakarta.

www. Bankirnews.com

www.bi.go.id 